\title{
THE CONTINUOUS CONSTRUCTING OF LINGUISTIC PATHWAYS IN THE EARLY STAGES OF SLA
}

\author{
Fernando G. Ferreira-Junior ${ }^{1}$
}

Resumo: A aprendizagem de uma língua é regida por processos gerais de diferenciação e generalização, cujos mecanismos cognitivos também operam em outros tipos de aprendizagem. Tal processo envolve a percepção de tokens altamente frequentes no insumo; dentre estes um se tornará mais prototípico, facilitando assim o desenvolvimento de uma dada categoria balizado pela frequência de types em espaços representacionais específicos. O presente artigo busca fornecer evidências adicionais de aprendizagem de L2 baseada no uso à luz de dados empíricos recentes. Com este intuito é feita, inicialmente, uma síntese da teorização acima delineada; seguem-se uma re-análise e discussão, na forma de redes de colocações de palavras, de dados longitudinais de aprendizes de L2 publicados recentemente (FERREIRA-JUNIOR, 2008; ELLIS; FERREIRA-JUNIOR, 2009a, 2009b). As conclusões evidenciam que o desenvolvimento linguístico dos aprendizes é caracterizado por uma construção contínua de 'rotas linguísticas' alternativas ao longo do processo de constante mapeamento entre função e forma.

Palavras-chave: insumo, freqüência, categorização, construções, aquisição de segunda língua, aprendizagem de línguas.

\footnotetext{
1 Lecturer in English at Instituto Federal de Minas Gerais, Ouro Preto campus, Brazil. Email fernando.ferreirajunior@ifmg.edu.br . I thank two anonymous reviewers for their helpful comments on an earlier version of this paper. This paper is mostly based on discussions from chapter seven of my $\mathrm{PhD}$ dissertation.

Organon, Porto Alegre, nº51, julho-dezembro, 2011, p. 145-169
} 


\section{INTRODUCTION}

First and second language acquisition (L1 and L2) studies seem to be recently converging on central or universal cognitive aspects involved in the learning of languages. Once kept apart by idealizations about a Universal Grammar (UG) and critical periods in language learning, research in L1 and L2 learning is breaking the boundaries between language use and abstract knowledge of language structure. The traditional distinction between lexis and grammar is no longer taken as a dogma as constructionist and usage-based approaches of language learning and use present more and more empirical evidence (mainly based on corpora) that abstract language structure is continuously constructed from small concrete pieces of language.

In this paper I present the results of a more qualitative analysis of English L2 learner longitudinal data recently published (FERREIRA-JUNIOR, 2008; ELLIS; FERREIRA-JUNIOR, 2009a, 2009b). In what follows, I briefly explain the concept of construction and comment on some recent theorizing about grammatical knowledge and the roles of token and type frequencies in language learning. Then, some collocational networks analyses are carried out, results presented and discussed ${ }^{2}$.

\section{CONSTRUCTIONS}

Constructions, recurrent and entrenched pairings of form and meaning/function, constitute the basic building blocks throughout the entire process of language learning. As claimed by Goldberg (2006), constructions are learned (or induced) on the basis of input exposure and driven by general cognitive, pragmatic, and processing constraints (i.e., by general psychological principles of category learning). Examples of constructions, after Goldberg (2003:220), are provided in Figure 1:

2 Although I'm the only author of the present paper, I understand it's the result of previous collective research and that is the reason why the pronouns $I$ and we are used throughout it. 


\begin{tabular}{|l|l|l|}
\hline Construction & Form/Example & Function \\
\hline root words & e.g., book, dog, or & \\
\hline Complex word & e.g., Daredevil, shoo-in & \\
\hline Idiom (filled) & e.g., go nuts & $\begin{array}{l}\text { Meaning: linked } \\
\text { independent and dependent } \\
\text { variables }\end{array}$ \\
\hline Idiom (partially filled) & e.g., drive <someone> crazy \\
\hline $\begin{array}{l}\text { Covariational- } \\
\text { constructional }\end{array}$ & $\begin{array}{l}\text { Form: The Xer the Yer (e.g., the more } \\
\text { you think about it, the less you } \\
\text { understand }\end{array}$ & $\begin{array}{l}\text { Meaning: transfer (intended } \\
\text { or actual) }\end{array}$ \\
\hline $\begin{array}{l}\text { Ditransitive (double } \\
\text { object) construction }\end{array}$ & $\begin{array}{l}\text { Form: Subj [V Obj1 Obj2] } \\
\text { (e.g., He baked her a carrot cake.) }\end{array}$ & $\begin{array}{l}\text { Fiscourse function: to make } \\
\text { undergoer topical and/or } \\
\text { (e.g., The house was hit by lightening }\end{array}$ \\
\hline Passive & actopical \\
\hline
\end{tabular}

Figure 1: Some constructions, varying in size and complexity; notice that function need not be specified when form is transparent

The creative and infinite aspects of language come from the unlimited possibilities of (re)combinations of chunks of language in our mental stock of constructions. Constructions freely merge with other constructions in order to express new and different meanings. So, what is grammatical competence from such a perspective? Simply put, it can be understood as a collection of constructions - a constructicon - gradually built up throughout our lifetime. So, time with language seems to be fundamental in language learning; indeed, as commonsensically put by Ortega; Iberri-Shea (2005:26), SLA 'can be most meaningfully interpreted only within a full longitudinal perspective'. Grammatical competence is thus understood here as a huge collection of constructions along a continuum (which varies in specificity and complexity from concreteness to abstractness) ranging from morphemes, words, complex words, idioms, semi-productive patterns and, ultimately, fully abstract phrasal patterns. That is the rationale behind recent empirical and theoretical investigations conducted by Goldberg and colleagues in 2008, 2006, 2004, 2003; Bybee, 2008; Ellis, 2008, 2009; Lieven and Tomasello, 2008; Gries and Wulff, 2005; Tomasello, 2003; to name a few. 


\section{THE EMERGENCE OF GRAMMAR: CHUNKING AS A CATE- GORIZATION BY-PRODUCT}

Bybee (2008) suggests that grammatical knowledge is procedural knowledge. This cognitive organization of our linguistic experience is made possible through processes of chunking. Chunking enables the creation of constructions. Such memory mechanisms operate slowly and govern processes of categorization, generalization and knowledge differentiation (as advocated by MCCLELLAND; ROGERS, 2003). These sequences, which are neuromotor in nature, lead to chunking which leads in turn to grammaticization. So, grammaticization is a procedural memory phenomenon. In the same vein Ellis $(2002,2003)$ suggests that both native and proficient speakers know an enormous amount of linguistic sequences in different levels (phonological, morphosyntactic) and, through the unconscious learning of the regularities present in the linguistic input, end up learning as well the sequential probabilities of a particular language in all these levels. Chunking processes seem to be at the heart of language learning and, from a constructionist perspective, the much idealized grammatical competence can be conceived as just strings of crystallized or entrenched patterns. These 'patterns' are the constructions themselves, i.e., recurrent and entrenched pairings of form and meaning/function of various degrees of specificity and complexity, as noted before.

\section{CRACKING THE CODE: PATHBREAKING VERBS}

With the help of large corpora it is becoming more and more possible to study the statistical regularities of linguistic structure. Recent studies have shown that some verbs (highly frequent ones) seed the development of argument structure constructions. These are called prototypical or pathbreaking verbs (GOLDBERG, 2006; GOLDBERG et alii., 2004) in the sense that they are the best cue to overall sentence meaning, i.e., who does what to whom.

Research by Goldberg and colleagues $(2006 ; 2004)$ on L1 acquisition of verb argument constructions (VAC) provide evidence on how meaning and form correspondences involving intransitive motion (VL label for verb locative), caused-motion (VOL label for verb object locative) 
and ditransitive or double-object (VOO label) constructions ${ }^{3}$ have their genesis in verb-centred categories or what Tomasello (2003) named verb island hypothesis. The developmental pattern found for the acquisition of these VACs basically follows this fashion: first children conservatively produce syntactic patterns on a 'verb island' basis. It means that one single verb occurs with very high frequency when compared to the other types found in the same constructional pattern; that is, a 'prototype verb' takes the lion's share of a specific construction, i.e., go for VL, put for VOL and give for VOO. Next, argument slots begin to be slowly filled with other verbs in the ultimate process of generalising over specific verbs, thus forming children's knowledge of argument structure patterns. Results on mothers' data also show the preponderance of a single verb dominating a construction type (see Goldberg et alii., 2004). Ellis and Ferreira-Junior (2009a, 2009b) tested the 'verb island hypothesis' with L2 English learners. Results show a similar pattern for L2 learning as far as the VACs investigated are concerned. They also lend support to an important crosssectional study on the role of constructions in SLA reported by Gries and Wulff (2005), thus strengthening the ontological status of constructions in second language acquisition (SLA) research.

\section{INPUT FREQUENCY AND ZIPF'S LAW}

One of the first to point to the statistical (or probabilistic) nature of language was the American philologist George Zipf in 1935. Zipf proposed that highly frequent words account for most linguistic tokens in a text. And verb frequency results for VL, VOL and VOO constructions found in our data seem to confirm what came to be known as Zipf's Law. And there is indeed a preponderance of highly frequent verbs for each construction investigated here. It aids the learner tremendously during communication, because, as these verbs are much more frequent, they become more relevant in differing contexts of use. This Zipfian family profile later facilitates the learning of the meaning of the abstract pattern. This happens because some verbs in isolation have low cue validity as predictors of sentence meaning. So learners will ultimately rely on constructions because sometimes these are better predictors of overall meaning than many verbs.

3 Please check the Appendix for further explanation of the VL, VOL and VOO constructions discussed along these pages.

Organon, Porto Alegre, nº 51, julho-dezembro, 2011, p. 145-169 
Lieven and Tomasello (2008) point to frequency as a crucial factor in language learning. For instance, weird-word order experiments in which non-canonical orders are presented show that children tend to correct mostly to canonical word order with verbs they know than with novel verbs. There are different kinds of frequency and they have differential effects. Token frequency 'entrenches' the comprehension and use of concrete pieces of language - items and phrases, as a chunk. Type frequency, on the other hand, promotes generalization, i.e., type frequency allows for the understanding of the internal structure of a given utterance, leading the learner to noticing that different items may serve the same function within the context of the very same construction. It is a necessary condition to the development of abstract language structures (grammar): "the difference between token and type frequency is between entrenching specific words or phrases and creating slots in which a range of words or phrases can occur" (LIEVEN; TOMASELLO, 2008, p.174).

In order to refine previous analyses (FERREIRA-JUNIOR, 2008; ELLIS; FERREIRA JUNIOR, 2009a, 2009b) we present in the remainder of this paper some collocational network analyses carried out on the same longitudinal data, i.e., from learners of English as a Second Language (ESL) in the European Science Foundation Project - henceforth ESF Project (see PERDUE, 1993). In the original publications aforementioned the reader will find the methodological details, results, and previous analyses.

\section{INDIVIDUAL CUMULATIVE ACQUISITION CURVES}

As noted, our analyses are based on longitudinal data for seven ESL learners from the ESF Project living in Britain at the time of data collection (an approximately 30-month period in the early 1980's), whose native languages were Italian (four of them) and Punjabi (the other three). Their conversational data transcriptions were carefully analyzed after being downloaded from the Max Planck Institute for Psycholinguistics (MPI), in Nijmegen, The Netherlands'. We decided to look at learners' individual developmental patterns through their cumulative acquisition curves for the prototypical verbs and their collocations (highly frequent word co-occurrences) in each construction (VL, VOL and VOO). Such analyses might

4 The reader can have access to the set of data analyzed here from the MPI webpage at http://corpus1.mpi.nl/ds/imdi_browser/ . In the IMDI Browser one can find, inter alia, the ESF Corpus from the ESF Project (along with a detailed description of it).

Organon, Porto Alegre, nº 51, julho-dezembro, 2011,p. 145-169 
reveal a more accurate picture of important aspects of interlanguage development as far as collocations and constructions are concerned.

\subsection{Graph results for VL, VOL and VOO individual cumulative ac-} quisition curves

In this section we present a set of 19 small graphs for the individual acquisition curves in the three constructions analyzed. Each individual cumulative curve graph represents a learner's constructional development. Such graphs present the two most frequent verbs in each construction. The reader finds in Figure 3 further below a list of the most frequent verbs in each construction for all seven learners with percentages.
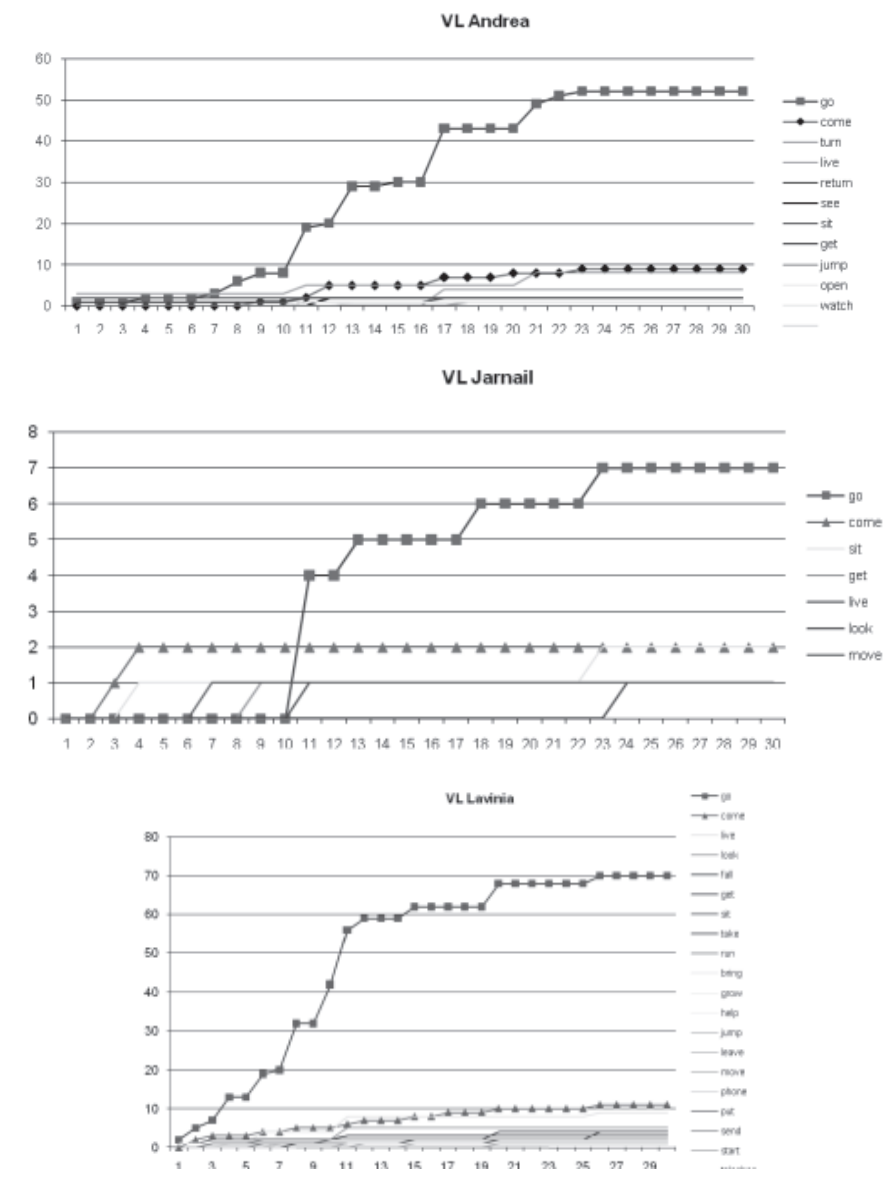

Organon, Porto Alegre, nº 51, julho-dezembro, 2011, p. 145-169 
VL Vito

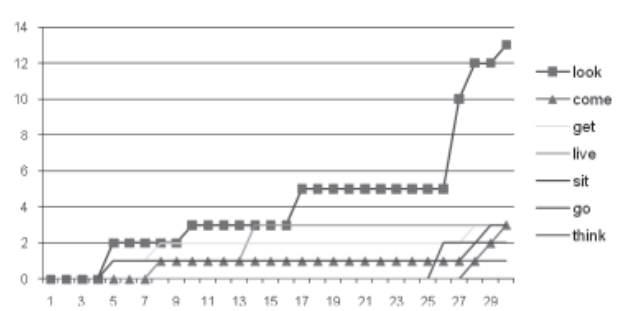

vLMaden

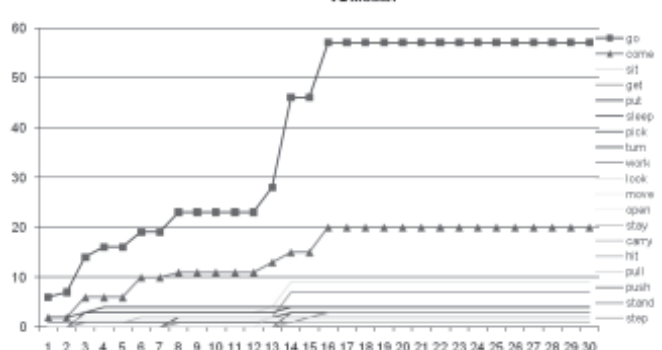

1234587899101112131415181718192021222324252827282930.

\section{VL Ravinder}

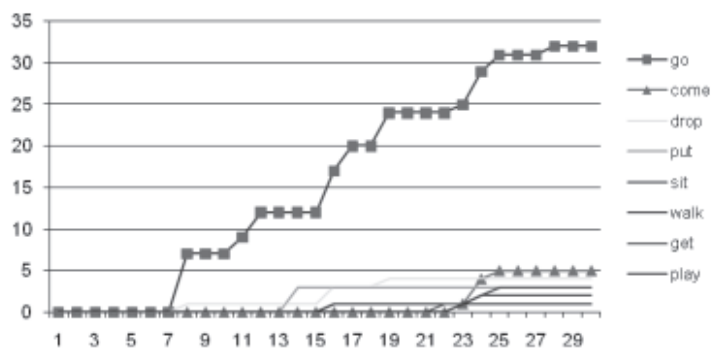

VL. santo

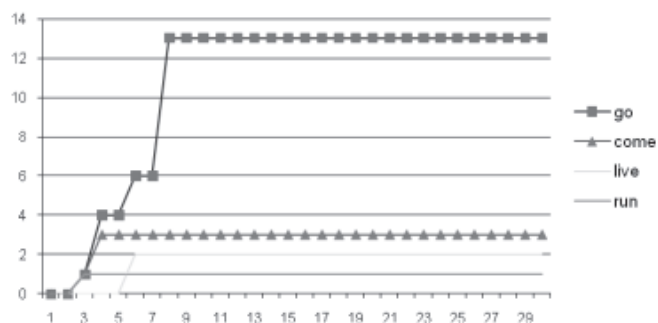

Organon, Porto Alegre, nº 51, julho-dezembro, 2011, p. 145-169 


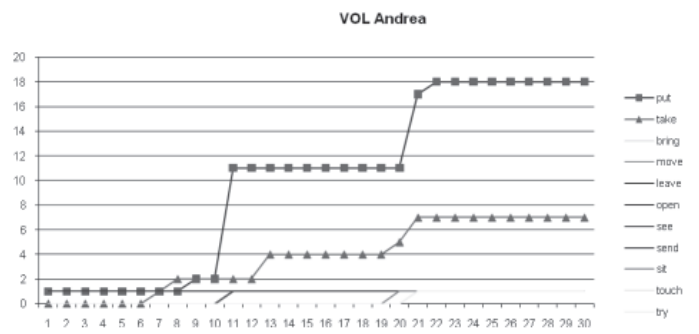

VoL Jarnail

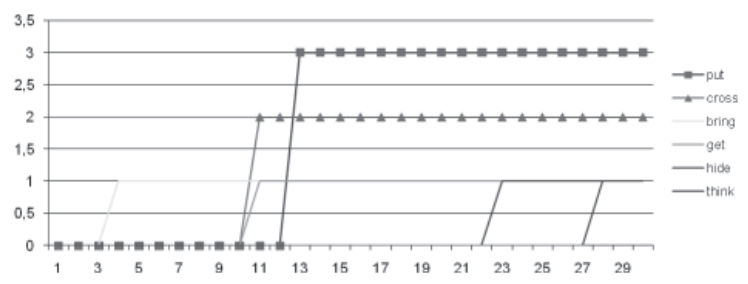

VoL Lavinia

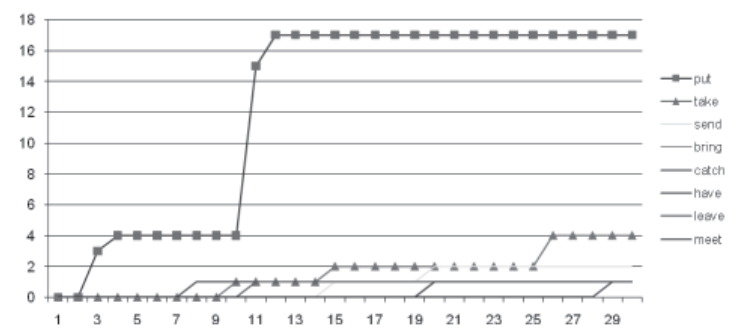

VOL Vito

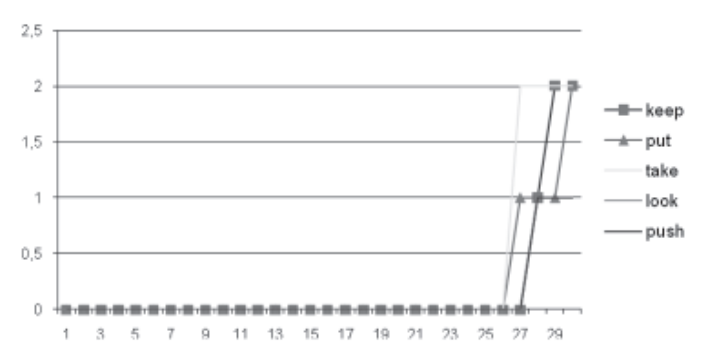

Organon, Porto Alegre, nº 51, julho-dezembro, 2011, p. 145-169 


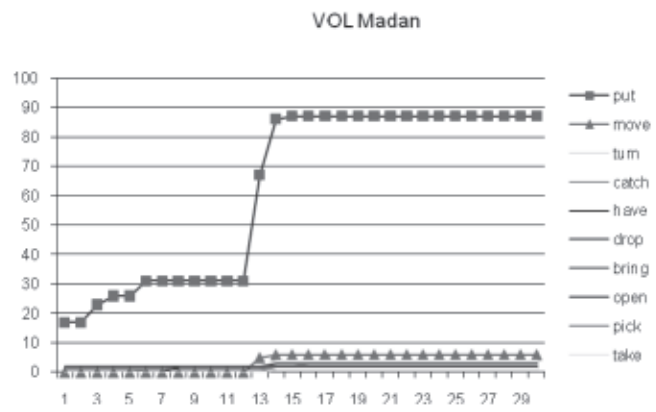

VOL Ravinder

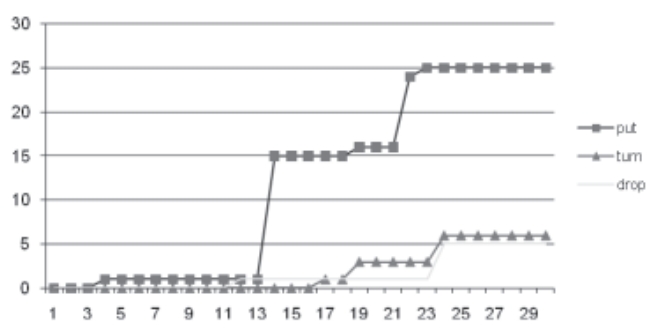

voo Andrea

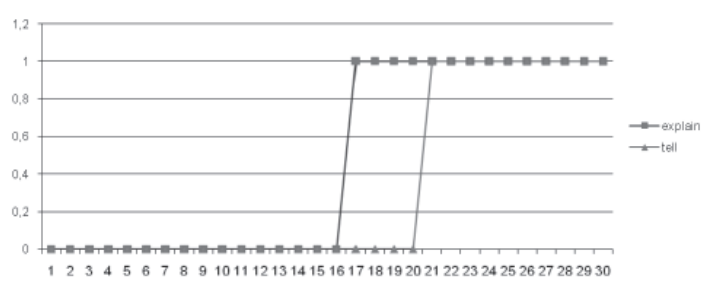

voo Lavinia

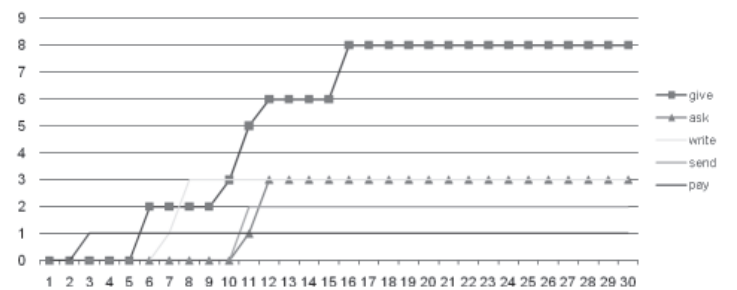

Organon, Porto Alegre, nº 51, julho-dezembro, 2011, p. 145-169 
voo Vito

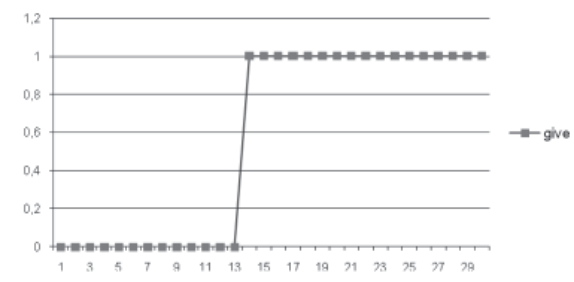

voo Madan

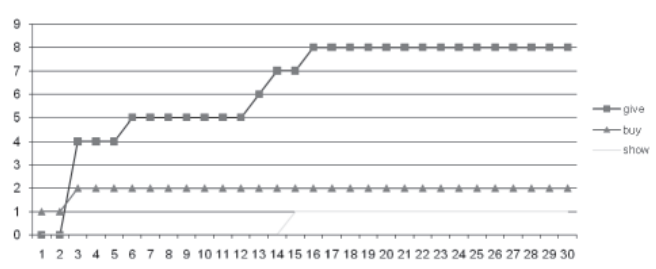

VOO Ravinder

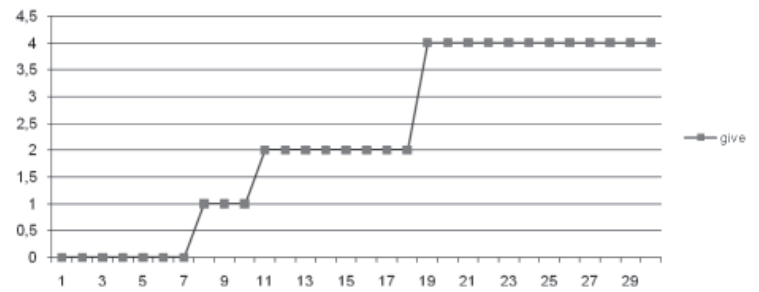

VOO santo

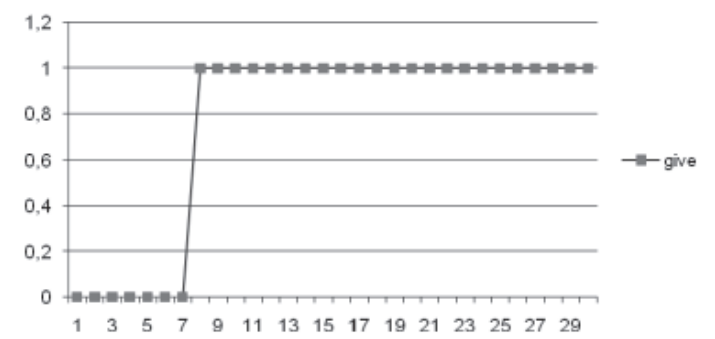

Figure 2: Set of 19 small individual acquisition curves for the three constructions analyzed. Note that axis $\mathrm{X}$ shows subject's study month while axis $\mathrm{Y}$ shows cumulative type frequency

Organon, Porto Alegre, nº 51, julho-dezembro, 2011, p. 145-169 
The graphs for individual cumulative curves exhibited above are important in providing evidence for the role of pathbreaking verbs in seeding the development of VACs. In fact it is possible to confirm that the frequency distribution of verbs in the verb islands is Zipfian and that the first verbs to emerge in each VAC are those most frequent, prototypical and more distinctively associated with a given construction island in the input. Although these graphs are quite helpful in identifying the gradual emergence of pathbreaking verbs along the first months of SLA, they are not a good index of the emergence of collocations and their dynamics. The above graphs reflect a somewhat static and linear state of language development. In order to get a glimpse into some of the dynamics of SLA we will focus our analysis on collocational networks based on our ESF data. In closing this section, Figure 2 below provides a summary of the most frequent verbs in each construction for each learner. Then a discussion section presents some word collocation networks for charting language development through the emergence of associative networks.

\begin{tabular}{|c|c|c|c|}
\hline Learners & VL & VOL & $\mathrm{VOO}$ \\
\hline Andrea & $\begin{array}{l}\text { go } 52 / 76(68 \%) \\
\text { come } 8 / 76(10 \%)\end{array}$ & $\begin{array}{l}\text { put } 18 / 33(54 \%) \\
\text { take } 7 / 33(21 \%)\end{array}$ & $\begin{array}{c}\text { tell } 1 / 2(50 \%) \\
\text { explain } 1 / 2(50 \%)\end{array}$ \\
\hline Ravinder & $\begin{array}{l}\text { go } 32 / 51(62 \%) \\
\text { come } 5 / 51(9 \%)\end{array}$ & $\begin{array}{l}\text { put } 25 / 36(69 \%) \\
\text { turn } 6 / 36(16 \%)\end{array}$ & give $4 / 4(100 \%)$ \\
\hline Lavinia & $\begin{array}{c}\text { go } 70 / 123(56 \%) \\
\text { come } 11 / 123(8 \%)\end{array}$ & $\begin{array}{l}\text { put } 17 / 28(60 \%) \\
\text { take } 4 / 28(14 \%)\end{array}$ & $\begin{array}{c}\text { give } 8 / 17(47 \%) \\
\text { ask/write } 3 / 17(17 \%)\end{array}$ \\
\hline Madan & $\begin{array}{c}\text { go } 57 / 123(46 \%) \\
\text { come } 20 / 123(16 \%)\end{array}$ & $\begin{array}{l}\text { put } 87 / 109(79 \%) \\
\text { move } 6 / 109(5 \%)\end{array}$ & $\begin{array}{l}\text { give } 8 / 11(72 \%) \\
\text { buy } 2 / 11(18 \%)\end{array}$ \\
\hline Vito & $\begin{array}{c}\text { look } 13 / 28(46 \%) \\
\text { come/get } / \text { live/sit } 3 / 28(10 \%) \\
\text { go } 2 / 28(7 \%)\end{array}$ & $\begin{array}{c}\text { put/keep/take } 2 / 8(25 \%) \\
\text { look/push } 1 / 8(12 \%)\end{array}$ & give $1 / 1(100 \%)$ \\
\hline Santo & $\begin{array}{c}\text { go } 13 / 19(68 \%) \\
\text { come } 3 / 19(15 \%)\end{array}$ & no construction found & give $1 / 1(100 \%)$ \\
\hline Jarnail & $\begin{array}{c}\text { go } 7 / 15(46 \%) \\
\text { come/sit } 2 / 15(13 \%)\end{array}$ & $\begin{array}{c}\text { put } 3 / 9(33 \%) \\
\text { cross } 2 / 9(22 \%)\end{array}$ & no construction found \\
\hline
\end{tabular}

Figure 3: Summary of the two most frequent verbs in each construction for each learner with percentages

\section{DISCUSSION}

7.1 Charting language development through the emergence of collocational networks

One very useful way to understand some language learning processing phenomena is through the use of collocational networks. That is 
what we will do in this section as we try to better understand the graphs shown in the section before. Ellis, Ferreira-Junior and Ke (unpublished manuscript) and Ke (2007) provide some additional evidence on how structure may emerge from the dynamics of an emergent mental lexicon, as proposed by Elman (2004) in the realm of lexical representation. These associative nets, called egonets, were originally developed for the analysis and interpretation of complex social and human relations. Such networks may thus provide a new way to look at and understand the old problem of language development. First, three nets representing VL, VOL and VOO constructions were created. They were built by simply feeding all the constructions found in the ESF study into a computer program ${ }^{5}$. The words are taken as nodes and the adjacent collocations are the links. Collocational strength is measured by the thickness of the links. Collocation networks like these may reveal the genesis of abstract argument structure constructions of a given language. For example, Figure 4 below shows a network generated for VL constructions in our ESF data:

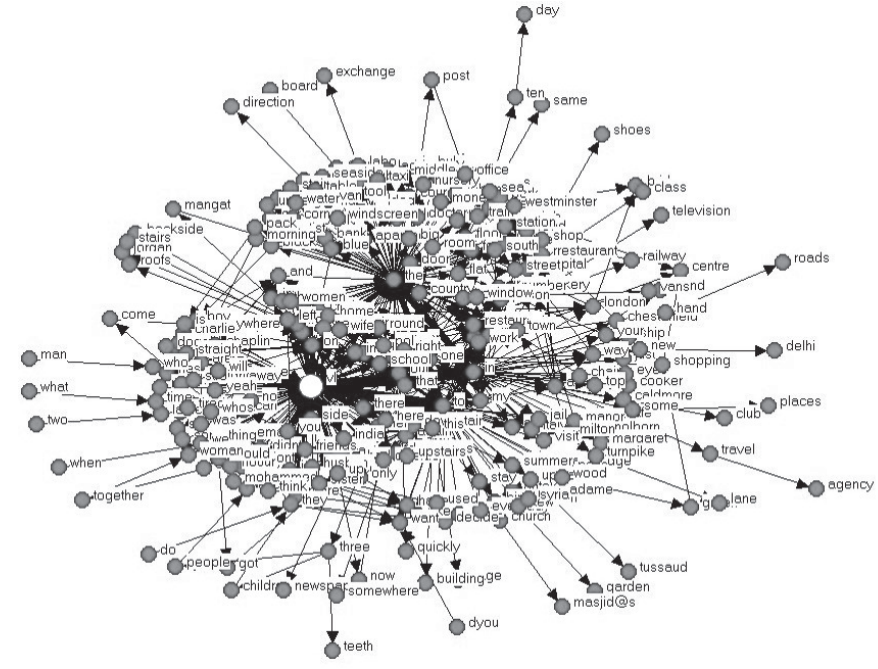

Figure 4: Collocational network for all words in the 436 VL learner constructions

$5 \quad$ I thank my colleague Jinyun Ke for teaching me how to use NetDraw, version 2.043, which allowed me to plot such networks. Jinyun's insights have inspired me on some of the network analysis carried out here.

Organon, Porto Alegre, nº 51, julho-dezembro, 2011, p. 145-169 
As seen above, the emerging network is rather chaotic. Perceiving the internal collocational patterning is something impossible due to vocabulary overlapping in multidimensional spaces. Now look at a sub-net for all VL constructions revolving around the lemma come, i.e., including the forms come, coming and came (Figure 5). The net below is in fact embedded into the connections of the net shown before.

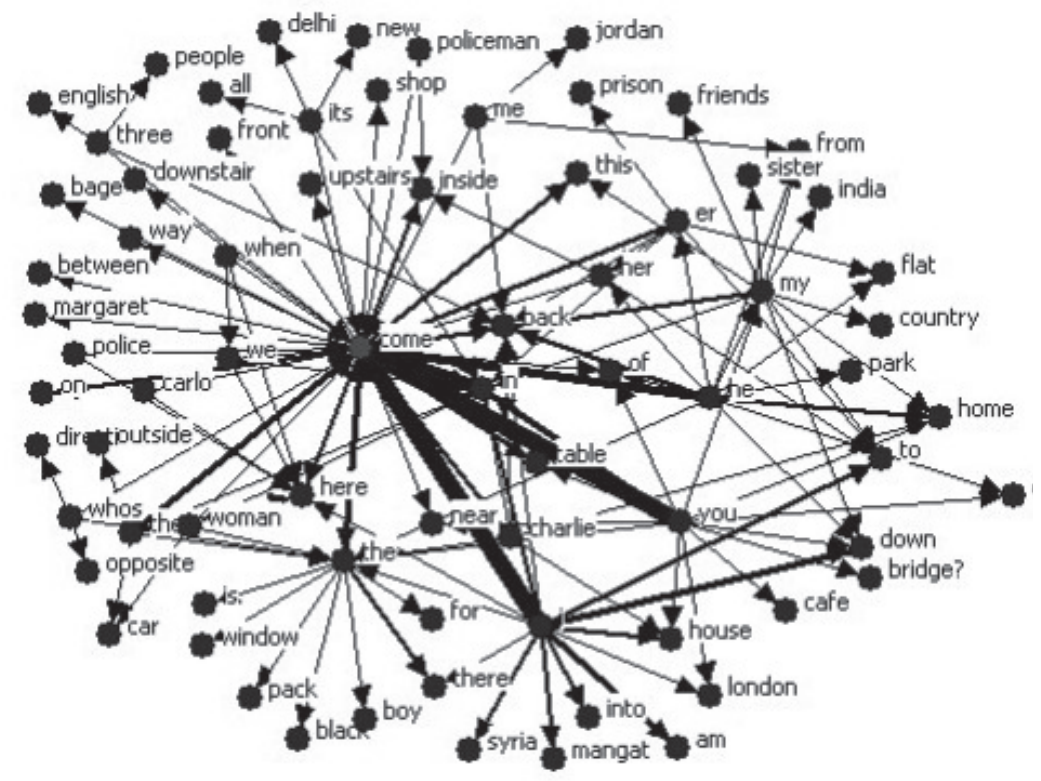

Figure 5: Collocational network for all words in all VL learner constructions with the verb come

The probabilistic tuning of the co-occurrence of words (as shown in Figure 5) enables the identification of collocations, pivot schemas and verb islands in a given construction (note that such schemas are identifiable by the thickness of links among words). By using this kind of representation we can more easily identify and better understand the patterning behavior of collocations in the early stages of SLA. So, the further fine-tuning of Figure 5 leads to Figure 6 below in which a VL schema (i.e, agent + verb + locative or subject + verb + preposition) is clearly identifiable; this emergent constructional 
pattern results from the frequency of occurrence of a group of pronouns in the agent slot and a group of prepositions in the locative slot. As a result of being continuous, this network behavior ultimately leads to entrenchment.

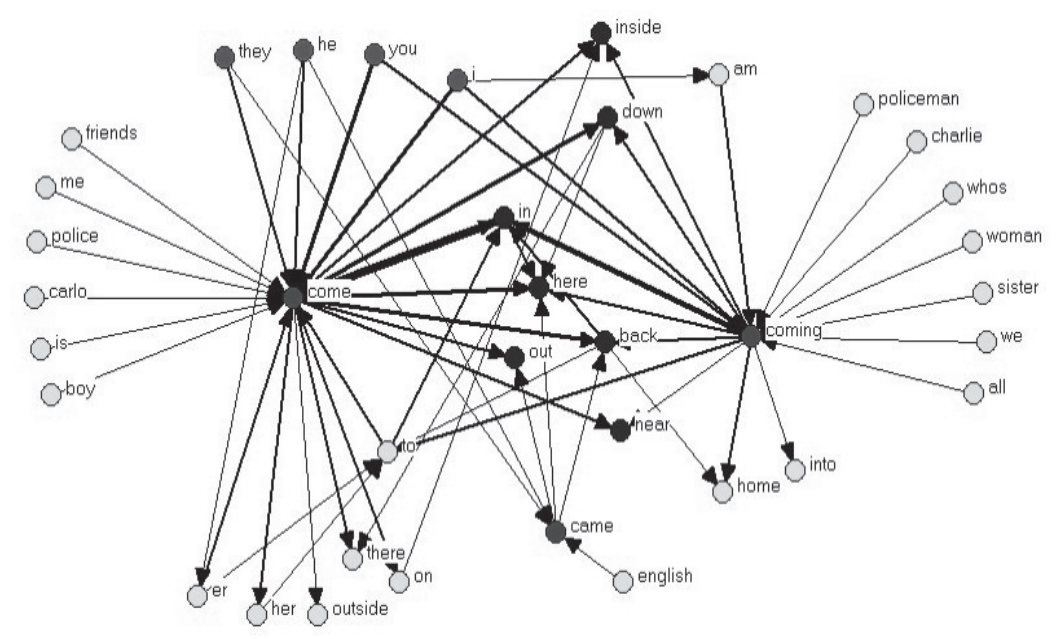

Figure 6: Collocational network for all pronouns and prepositions in all VL learner constructions with the verb come in the ESF corpus

As discussed before, these pivot schemas and verb islands seem to be the genesis of abstract constructional categories. Next we take a brief look at some collocational networks for all VL, VOL and VOO constructions. Note that they follow the same pattern shown in the example given above for VL constructions with the lemma come.

\subsection{The continuous constructing of linguistic pathways}

In this section we provide three collocational networks for all verb constructions from the ESL corpus. They are not lemmatized but revolving around an abstract verb island schema. Note that the structural combinations at this point (30 month or a two and half years) of ESL acquisition are quite interesting and some entrenchment can easily be identified. First, in Figure 7, the collocations network for VL constructions:

Organon, Porto Alegre, nº 51, julho-dezembro, 2011, p. 145-169 


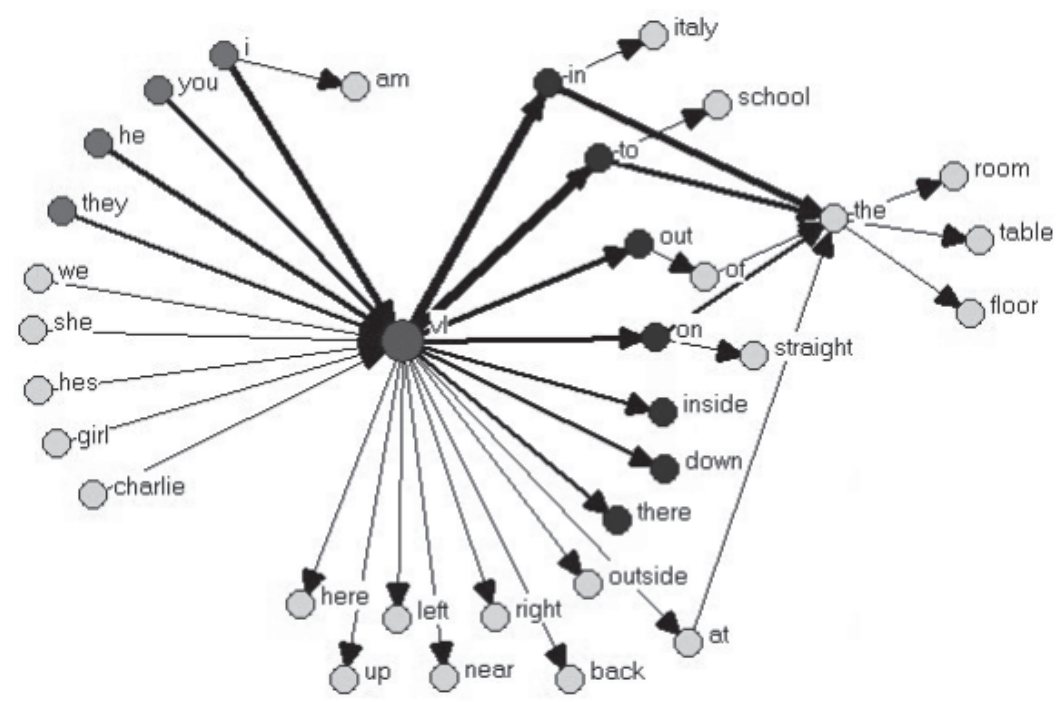

Figure 7: Collocational network for 436 VL learner constructions in the ESF corpus

As can be seen, the constructing process is initially verb-based but then, at a certain point, becomes chunked in a collocation-based fashion. At that stage there is a deconstruction of some initial pathways (thin lines) as alternate pathways (thick lines) starts to be built. Then VAC utterances gradually emerge and become longer as time passes; also notice it happens in tandem with the constructing of new pathways (adjacent lines). Thus based on the VL collocational network shown in Figure 7 we can chart in Figure 8 the emergence of the VL construction along the 32 month period analyzed so as to check at what point new pathways are chosen and linguistic restructuring occurs. If we do this, we find out that initially two or three-word VAC utterances gets longer on average as time passes:

\begin{tabular}{|l|l|}
\hline Subjects'acquisition month & bare VL construction \\
\hline 1 & go out \\
\hline 1 & sit down \\
\hline 1 & come here? \\
\hline 1 & come here \\
\hline 3 & police come here \\
\hline
\end{tabular}

Organon, Porto Alegre, nº 51, julho-dezembro, 2011, p. 145-169 


\begin{tabular}{|l|l|}
\hline 3 & you put here \\
\hline 3 & you sit down \\
\hline 4 & he going out \\
\hline 4 & he go out quickly \\
\hline 7 & look out in my house \\
\hline 8 & i go to the restaurant \\
\hline 8 & i went to a bakery \\
\hline 10 & he went to the dentists \\
\hline 11 & she went in the room \\
\hline 12 & go to the police station \\
\hline 12 & you go to Birmingham \\
\hline 13 & back side move to front \\
\hline 14 & he go to inside the shop \\
\hline 14 & he go to the police station \\
\hline 15 & three children they go off to work \\
\hline 15 & i used to go to my friend house \\
\hline 16 & me come back from Jordan \\
\hline 17 & the chemist is in the turnpike lane road \\
\hline 21 & mohammed go to church masjid@s \\
\hline 22 & he went in the rrestaurant \\
\hline 22 & whos coming the opposite direction \\
\hline 23 & come in this way between the table \\
\hline 26 & my sister coming to in this country from india \\
\hline 26 & i am coming into mangat house \\
\hline 29 & look in the round and round the in the room \\
\hline 30 & look in the number in the calendar \\
\hline 32 & look at the windscreen \\
\hline 32 & coming in the shop \\
\hline
\end{tabular}

Figure 8: A sample of VL VAC utterance length as related to subject's study month

The very same pattern is found in the analysis carried out on VOL constructions. Figure 9 below shows a collocational network for all 224 VOL learner constructions. Again, the constructing process is initially verb-based but then, at a certain point, becomes chunked in a collocation-based fashion (though, for the VOL data we have, not so robust as seen in the precedent discussion). At this stage, there is a deconstruction of some initial pathways (thin lines) as alternate pathways (thick and darker lines) start to build up. Figure 11 further below demonstrates how VAC utterances get longer as time passes and the constructing of new pathways takes place. Later, VAC utterances tend to get shorter again (maybe due to the continuous repackaging process) by chunking. 


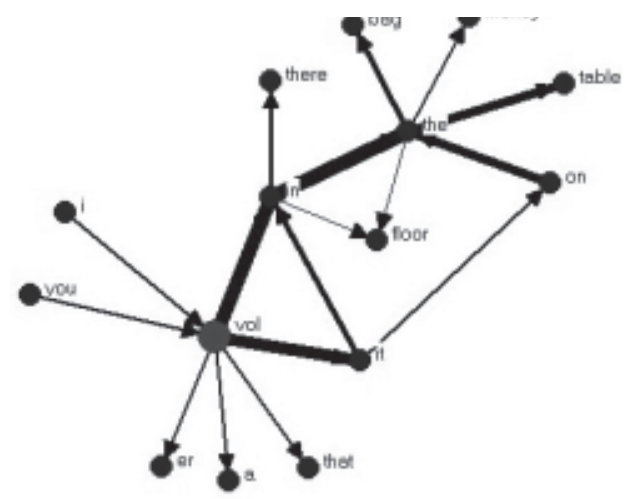

Figure 9: Collocational network for 224 VOL learner constructions in the ESF corpus

Figure 10 below allows an interesting comparison of collocational patterns for VOL constructions found in learners' and NS's constructions. Remember that in VOL constructions a verb is followed by an object and a location. We can see in Figure 10 that the pronouns you and $I$ are the most frequent words in the construction's subject slot. By comparing learners' and NS's collocations network we can see an interesting difference: in the learners' network there is a strong connection between the verb and the preposition in, whereas in the interviewer's network there is no such a connection; instead, the strongest connection is between the verb and the object pronoun, which is not present in the learners' network. This difference is illustrated by the arrows. Such a difference may be due to learners' ungrammatical constructions such as put in the table (as seen in Figure 11), in which the object pronoun in the VOL construction is missing.
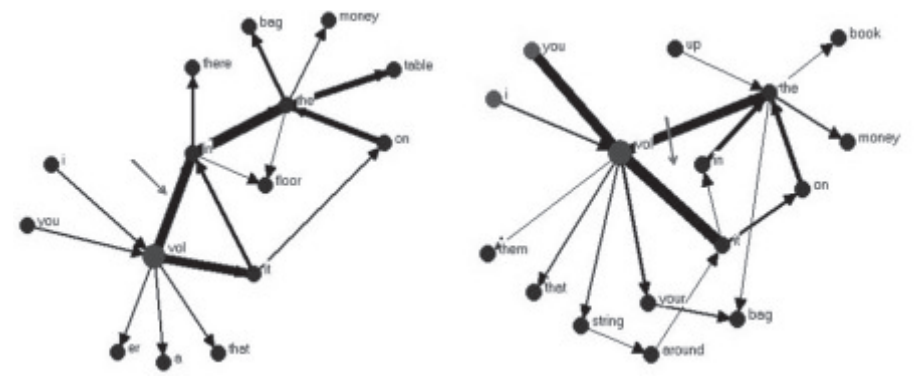

Figure 10: Comparing collocations network for learners' and NS's VOL constructions in the ESF corpus Organon, Porto Alegre, nº 51, julho-dezembro, 2011, p. 145-169 


\begin{tabular}{|c|c|}
\hline Subjects' acquisition month & Bare VL construction \\
\hline 1 & put in there money \\
\hline 1 & put in the table \\
\hline 1 & put it up the book \\
\hline 1 & money put in there \\
\hline 1 & put in the table \\
\hline 1 & put in there \\
\hline 1 & scrap job put in there \\
\hline 3 & you put in your bag \\
\hline 4 & bring baq here \\
\hline 4 & top put in the book \\
\hline 6 & put it er top the table \\
\hline 6 & put in the floor baq \\
\hline 6 & he put in the till the money \\
\hline 7 & you take the coach for birmingham? \\
\hline 8 & catch the seventy eight from byron road to culver lane \\
\hline 8 & after come down [/?] coming \# by m walking \\
\hline 11 & put the bag with the silver over the cuscino \\
\hline 11 & put that baq in the last place on the shelf \\
\hline 11 & put the baq with the money in that baq \\
\hline 11 & there is one green bag on the floor \\
\hline 11 & put the baq in the corner near the cupboard \\
\hline 12 & put the sink on the other next to the door \\
\hline 13 & move this er dust bin please this way \\
\hline 13 & move the finger the on finger on in the photo \\
\hline 13 & move from backside more from here put in the back side \\
\hline 13 & keep it newspaper put in the bag \\
\hline 15 & i put in all money my daughter name \\
\hline 16 & catch the coach from turkey to antakia \\
\hline 22 & to send one letter into the postal box \\
\hline 23 & touch with your leg the box on the floor \\
\hline 23 & sit down in the chair behind the table \\
\hline 23 & put that near the legs of seige behind the table \\
\hline 28 & take me here the policeman \\
\hline 29 & take up the bag in the floor \\
\hline 30 & to think them over at home \\
\hline 30 & keep it bread in the van \\
\hline 30 & push charlie chaplin in the van \\
\hline 30 & look the police in the street \\
\hline 31 & to have a look at the leaflet \\
\hline 31 & keep the money in? \\
\hline 32 & put in this room all picture \\
\hline
\end{tabular}

Figure 11: VOL VAC utterance length as related to subject's study month

Finally, a similar pattern is found in the analysis carried out on VOO constructions. Figure 12 below exhibits a collocations network for all 36 VOO learner constructions. Note that the number of VOO constructions found in our data is quite small. Indeed, all of them are listed in Figure 13 further below

Organon, Porto Alegre, nº 51, julho-dezembro, 2011, p. 145-169 

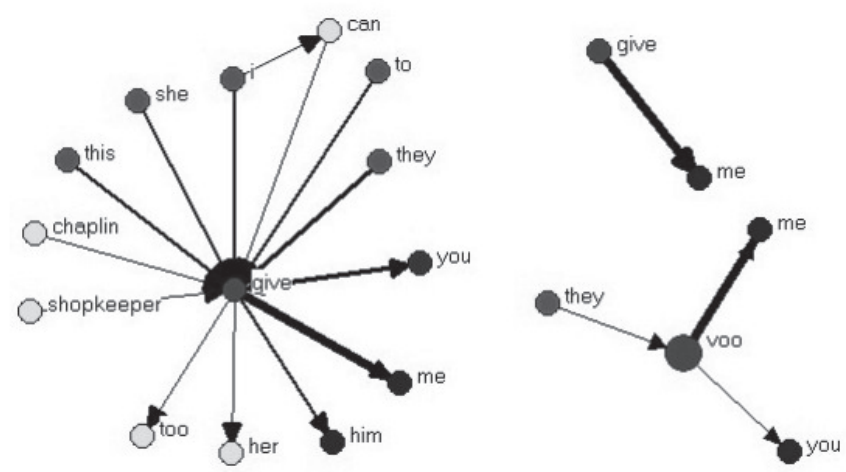

Figure 12: Collocation networks for 36 VOO learner constructions found in the ESF corpus

The constructing process is essentially verb-based for the data shown here. It did not reach a robust collocation-based pattern as observed in the two preceding discussions, though there is a deconstruction of some initial pathways (thin lines) as alternate pathways (thick lines) starts to be built. VAC utterances would certainly become longer as time passed and the constructing of new pathways took place. But we only have VOO construction data related to a 23-month period (less than two years) and very few instances of them. According to Goldberg et alii. (2004), VOO constructions are more complex and demand more time to be learned. But along the process of SLA the developmental pattern will certainly follow those found for the VL and the VOL constructions discussed earlier.

\begin{tabular}{|l|l|}
\hline Subjects' acquisition month & Bare VL construction \\
\hline 1 & i buy my daughters clothes \\
\hline 3 & i pay you these extra \\
\hline 3 & give me money \\
\hline 3 & shopkeeper qive me one cigar \\
\hline 3 & you give me money \\
\hline 3 & give me money \\
\hline 3 & ibuy my daughter er toys \\
\hline 6 & they qive me a cheque \\
\hline 6 & they give me an apartment \\
\hline 6 & she give me some money \\
\hline 7 & she wrote me a letter \\
\hline 8 & my sister wrote me a letter \\
\hline
\end{tabular}

Organon, Porto Alegre, nº 51, julho-dezembro, 2011,p. 145-169 


\begin{tabular}{|l|l|}
\hline 8 & she wrote me two or three letter \\
\hline 8 & give me small packet \\
\hline 8 & charlie chaplin qive too money this woman \\
\hline 10 & to give him the money \\
\hline 11 & they give me a piece of paper \\
\hline 11 & to give her a parcel \\
\hline 11 & they ask you some question \\
\hline 11 & they send him a lot of bill \\
\hline 11 & the electricity board send us a bill \\
\hline 11 & this give me manqat \\
\hline 12 & they didnt ask you something \\
\hline 12 & i can qive him something \\
\hline 12 & they ask me about this courses \\
\hline 13 & she give me long time \\
\hline 14 & give me one cigar \\
\hline 14 & give me chance \\
\hline 15 & can you show me the picture \\
\hline 16 & they give you some questions \\
\hline 16 & they give you some answer \\
\hline 16 & i give you the money \\
\hline 17 & i explain you one way very simple \\
\hline 21 & give me hand \\
\hline 21 & you give me hand? \\
\hline 23 & she tell him the same thing \\
\hline
\end{tabular}

Figure 13: VOO VAC utterance length as related to subject's study month

\section{CONCLUSIONS}

Gries and Wulff (2005), in discussing the importance of a construction-based approach to SLA, point out that

Although foreign language learners have much less input in the foreign language than native speakers have in their native language, they are still able to arrive at generalizations that lend themselves to construction-based explanations. Therefore, accounts arguing against constructions on grounds of limited input are apparently on the wrong track. In addition, in spite of the various differences between first and second/ foreign language learning, the probabilistic nature of the results and their similarity to that obtained for native speakers provide strong additional support of exemplar based theories of second/foreign language acquisition in which frequency of exposure to, and use of, constructions play a vital rule (sic) (GRIES and WULFF, 2005, p.196).

Organon, Porto Alegre, nº 51, julho-dezembro, 2011, p. 145-169 
The analysis on the continuous constructing process presented in the above pages is complementary to our previous analysis (FERREIRAJUNIOR, 2008; ELLIS; FERREIRA-JUNIOR, 2009a, 2009b). It provides further evidence for the role of collocations in the early stages of SLA and sheds some light on how structure may emerge from the dynamics of an emergent mental lexicon. Such collocational networks provide a new way to look at an old problem; as seen throughout this paper, a more individual qualitative analysis into the utterances produced by the learners along the whole data collection period reveal more clearly some important developmental aspects of interlanguage, characterized by chunking processes in construction learning through emergent and entrenched collocational patterns. As discussed before, the constructional processes are continuous inasmuch as they constantly allow new pathways to emerge along the structuring and entrenchment processes of SLA.

The processes of constructional development discussed here resemble those of conceptual development proposed by Rogers and McClelland (2004). In fact, the continuous constructing, deconstructing and reconstructing of linguistic pathways evidenced by our analyses parallel those found in category development, i.e., differentiation and generalization. Our discussion also finds resonance in the neurobiology of learning. In fact, the 'knowledge' of language lies in the subtle connections established locally through inhibitory or excitatory weights, very like the neurobiological principle of learning proposed in 1949 by Donald Hebb. As we know, the Hebbian learning principle postulates that if any two neurons fire together (i.e., are simultaneously excited) the connection (synapse) between them must be strengthened (which, in turn, will consequently inhibit activations among other neurons) in such a way that, in subsequent occurrences of the same stimulus, these connections will exhibit higher levels of activations in the neuronal system due to their already constituting specific neuronal configurations or cell assemblies (O'REILLY; NORMAN, 2002, p.506-507).

I believe constructionist claims on language development would be strengthened if informed by theorizing from other areas of investigation such as neuroscience. It would add even more evidence and endorse recent claims that language can indeed be entirely learned from scratch. So far, to my view, this is an avenue not yet fully explored as far as SLA is concerned. 
Finally, echoing the words from Ortega and Iberri-Shea (2005) again, there is a scarcity of longitudinal studies in SLA, the prevalence being cross-sectional ones. Although cross-sectional studies have their place in providing important insights into the SLA processes, as the contribution by Gries and Wulff (2005) testifies, a full understanding of the processes underlying language learning is clearly dependent on time. As seen in our present discussion on construction learning by L2 English learners, time is a crucial factor in going from tokens to types to system in construction grammar (as put by ELLIS, 2009). Constructing a language takes time.

\section{ACKNOWLEDGEMENTS}

I thank my colleagues Fabio Alves, Nick Ellis and Jinyun Ke in this research. This research was supported in part by a doctoral grant from the Brazilian government through the CAPES Foundation, grant BEX 0043060, which allowed me to spend a year at the University of Michigan as a visiting scholar.

\section{APPENDIX}

\begin{tabular}{|l|l|l|}
\hline $\begin{array}{l}\text { VL (Intransitive Motion) } \\
\text { In English some verbs are used to } \\
\text { describe the movement of } \\
\text { something or someone }(\mathrm{X}) \text { to a } \\
\text { new place (Y) or in a new direction. }\end{array}$ & $\begin{array}{l}\text { VOL (Caused Motion) } \\
\text { In English some verbs are used to } \\
\text { describe how someone }(\mathrm{A}) \text { causes the } \\
\text { movement of something }(\mathrm{X}) \text { to a new } \\
\text { place (Y) or in a new direction. }\end{array}$ & $\begin{array}{l}\text { VOO (Ditransitive) } \\
\text { In English some verbs are used to } \\
\text { describe how someone (A) } \\
\text { causes someone (B) to receive } \\
\text { something (Z) }\end{array}$ \\
$\begin{array}{l}\text { e.g. The fly buzzed into the room } \\
\text { e.g. Pat blew the feather into the } \\
\text { drawer }\end{array}$ & e.g. Pat faxed Tom the picture \\
\hline
\end{tabular}

\section{REFERENCES}

BYBEE, Joan. Usage-based grammar and second language acquisition. In: PeterRobinson \& Nick C. Ellis (Eds.), Handbook of Cognitive Linguistics and Second Language Acquisition. Hillsdale, NJ: Lawrence Erlbaum, p. 216-236. 2008. 
ELLIS, Nick C. Frequency effects in language acquisition: A review with implications for theories of implicit and explicit language acquisition. Studies in Second Language Acquisition, vol. 24, p.143-188, 2002. ELLIS, Nick C. Constructions, Chunking, and Connectionism: The Emergence of Second Language Structure. In: C. Doughty \& M. H. Long (Eds.). The Handbook of Second Language Acquisition. Oxford, UK: Blackwell, p. 63-103. 2003.

ELLIS, Nick C. Phraseology: The Periphery and the Heart of Language. In: F. Meunier and S. Granger (Eds.), Phraseology in Foreign Language Learning and Teaching. Amsterdam: John Benjamins, p. 1-13. 2008.

ELLIS, Nick C. Optimizing the Input: Frequency and Sampling in Usage-based and Form-Focussed Learning. In: Michael Long \& Catherine Doughty (Eds.), Handbook of Language Teaching. Oxford: Blackwell, p.139-158, 2009.

ELLIS, Nick C.; FERREIRA-JUNIOR, Fernando. Construction learning as a function of frequency, frequency distribution, and function. The Modern Language Journal, 93(2), p.370-385, 2009a.

ELLIS, Nick C. \& FERREIRA-JUNIOR, Fernando. Constructions and their acquisition: Islands and the distinctiveness of their occupancy. Annual Review of Cognitive Linguistics (special section), vol. 7, p.187-220. $2009 \mathrm{~b}$. ELLIS, N. C., FERREIRA-JUNIOR, F., \& KE, J.-Y. (unpublished paper). Form, function, and frequency: Zipfian family construction profiles in SLA.

ELMAN, Jeffrey. An alternative view of the mental lexicon. TRENDS in Cognitive Sciences, vol. 8, n.7, p.301-306, 2004.

FERREIRA-JUNIOR, Fernando. Em Construção! Uma investigação acerca da natureza dos processos cognitivos envolvidos na aprendizagem de uma segunda língua. [online] PhD Dissertation available at http://dspace.lcc.ufmg.br/dspace/bitstream/1843/ALDR-7G7HCE/1/680d.pdf Universidade Federal de Minas Gerais, 250p. 2008. Last access on March 15, 2011.

GOLDBERG, Adele. Constructions at work: The nature of generalization in language. Oxford: Oxford University Press, 2006.

GOLDBERG, Adele. Constructions: a new theoretical approach to language. TRENDS In Cognitive Sciences, vol. 7, p. 219-224, 2003. GOLDBERG, Adele; CASENHISER, Devin. Construction learning 
and second language acquisition. In: Peter Robinson \& Nick C. Ellis (Eds.), Handbook of Cognitive Linguistics and Second Language Acquisition. Hillsdale: Lawrence Erlbaum, p.197-215, 2008.

GOLDBERG, Adele; CASENHISER, Devin; SETHURAMAN, Nitya. Learning argument structure generalizations. Cognitive Linguistics, vol. 15, p. 289-316, 2004.

GRIES, Stefan; WULFF, Stefanie. Do foreign language learners also have constructions? Evidence from priming, sorting, and corpora. Annual Review of Cognitive Linguistics, vol. 3, p. 182-200, 2005.

KE, Jinyun. Network analyses for language development \& language teaching. PowerPoint presentation. ELI Winter Seminar Series, University of Michigan, ELI, January 26, 2007.

LIEVEN, Elena; TOMASELLO, Michael. Children's first language acquisition from a usage-based perspective. In: Peter Robinson \& Nick C. Ellis (Eds.), Handbook of Cognitive Linguistics and Second Language Acquisition. Hillsdale, NJ: Lawrence Erlbaum, p.168-196. 2008.

McCLELLAND, James; ROGERS, Timothy. The Parallel Distributed Processing Approach to Semantic Cognition. Nature Neuroscience, vol.4, p.310-322, 2003.

O'REILLY, Randall; NORMAN, Kenneth. Hippocampal and neocortical contributions to memory: advances in the complementary learning systems framework. TRENDS in Cognitive Sciences, vol.16, n.12, p.505-510, 2002.

ORTEGA, Lourdes; IBERRI-SHEA, Gina. Longitudinal research in second language acquisition: recent trends and future directions. Annual Review of Applied Linguistics, vol. 25, p. 26-45, 2005.

PERDUE, Clive. (Ed.) Adult language acquisition: Crosslinguistic perspectives (Vol.2- The Results). Cambridge: Cambridge University Press, 1993.

ROGERS, Timothy; McCLELLAND, James. Semantic Cognition: A Parallel Distributed Processing Approach. Cambridge, MA: MIT Press, 2004. TOMASELLO, Michael. Constructing a Language: A Usage-Based Theory of Language Acquisition. Cambridge, MA: Harvard University Press, 2003. ZIPF, George K. The psycho-biology of language: An introduction to dynamic philology. Cambridge, MA: MIT Press. 1935.

Organon, Porto Alegre, nº51, julho-dezembro, 2011, p. 145-169 